\title{
TOPLUMSAL BAKIŞ AÇISIYLA EĞLENCE SEKTÖRÜ MÜZISYYNLIIĞI
}

\author{
Ünal İMİ** Ümit Uğur KAYA \\ 1: İnönü Üniversitesi, Devlet Konservatuvarı, Müzik Bölümü. \\ 2: Milli Eğitim Bakanlığı, Müzik Öğretmeni.
}

\section{Özet}

Günümüzde, eğlenceye sektörü müzisyenliğinin toplum içerisindeki bireyler tarafından nasıl bir değerlendirmeye tabi tutulduğu merak konusudur. Eğlence sektörü müzisyenlerine yönelik toplumsal bakışı tespit etmek amacıyla hazırlanana bu araştırmanın mevcut durumu ortaya koymayı hedeflemesi bakımından betimsel bir nitelik taşıdığı söylenebilir. Konu hakkındaki temel veriler dijital ve yazılı kaynak taraması ile elde edilmiştir. Bireylerin konu ile düşüncelerine yönelik verilerin toplanmasında ise anket tekniğinden faydalanılmıştır. Araştırmanın evrenini Malatya ilinde farklı sosyo-kültürel ve ekonomik yaşam düzeylerinde yaşayan farklı yaşlarda ve cinslerdeki bireyler, örneklemini ise rastlamsal yöntemle belirlenen ve anket uygulaması yapılan 750 örneklem oluşturmaktadır. Araştırmada eğlence sektörü müzisyenlerinin toplumdaki bireyler arasında saygın bir yer edinmelerinde aldıkları mesleki eğitimin niteliği ve derecesinin, mesleki kazançlarının miktarının, mesleki beceri ve performans seviyesinin önemli olduğu ulaşılan sonuçlardan bazılarıdır.

Anahtar Sözcükler: Müzik, Eğlence Sektörü, Müzisyenlik, Meslek, Toplum.

\section{SOCIAL PERSPECTIVE FOR ENTERTAINMENT INDUSTRY MUSICIANSHIP}

\begin{abstract}
Today, the entertainment industry is curious about how musicians are being evaluated by individuals in society. This study was designed to assess social perspective for mucisicians doing entertainment musicianship. It can be said that this study bear a descriptive nature in terms of targeting to reveal the current situation. Basic scientific data on the subject were obtained with scanning digital and printed literature. Survey technique was used for collection of data about individual perspectives. The study sample is consist of 750 individuals randomly chosen and surveyed among the individuals with different ages and sexes, living in different socio-cultural and socio-economic reagions of malatya province. Quality and degree of proffessional training; earnings and professional performance level are some of the resuts that we obtained from this study that are important for the mucisians doing entertaintment mucisianship in acquiring a respectable place in society.
\end{abstract}

Keywords: Music, Entertainment Sector, Musicianship, Business, Society.

\footnotetext{
* Yazışma yapılacak yazar: unal.imik@inonu.edu.tr

Bu makale, İnönü Üniversitesi Sosyal Bilimler Enstitüsünde gerçekleştirilen lisansüstü bir araştırmadan üretilmiştir.
} 


\section{Giriș}

Eğlence ihtiyacını karşılama fikrinin de bir parçası halini almış olan müzik sanatı, yaşadığımızda toplumda oldukça önemli bir yere sahiptir. Konfüçyüs müziği "bir eğitim aracı ve neşenin ifadesi” olarak vurgulamıştır (Fettahoğlu, 2003: 322).

Dinlenirken, alış veriş yaparken, yolculuk esnasında ve daha birçok zamanda müzik dinlemeye ihtiyaç duymaktadırlar. Sosyal içerikli programların dahi müzisyenlerin meydana getirdiği orkestralar eşliğinde sunulduğu günümüzde, eğlenceye yönelik yapılan müzisyenlik mesleğinin yaşantımızdaki rolü merak konusu olmaktadır.

Düğün, nişan, kına gibi geleneksel ve kültürel etkinliklerde sıkça karşılaşılan eğlence sektörü müzisyenleri ile yine toplumun eğlenceye yönelik ihtiyaçlarını karşılamak için tercih ettikleri bar, retoran, kafe gibi yerlerde de karşılaşmak mümkündür.

Toplumsal yaşantımızın önemli bir parçası olan müzik sanatı eğlence sektörü müzisyenliğinde toplumun psikolojik anlamdaki müziksel terapi ihtiyacına yardımcı olan bir hale dönüşmüştür.

\subsection{Eğlence Sektörü Müzisyenliği Kavramı}

Toplum, içerisinde yaşayan ve farklı meslek gruplarına sahip bireylerden meydana gelmektedir. $\mathrm{Bu}$ durum birlikte yaşamanın ve iş bölümü yapmanın getirdiği bir zorunluluk hali sergilemektedir. Toplum içerisindeki bireylerin beslenme, barınma diğer ihtiyaçları gibi eğlenmeye yönelik ihtiyaçları da zamanla ortaya çıkmıştır.

Bosshart ve Macconi’ye göre eğlence; insanların duygusal durum (mood) yönetimini iyileştiren bir alma (iletiyi) fenomeni olarak tanımlanmaktadır (Bosshart, Macconi 1998: 34). Eğlence birçok farklı yol ve biçimlerde gerçekleştirilebilir. Zillmann'da günümüzde gelişen teknolojinin ve üretim sektörünün daha çok eğlenceye hizmet ediyor olduğundan bahsetmektedir (Zillmann, 2000: 17). Özdemir'e göre ise, eğlence gelenekler bileşkesidir. Bu nedenle de eğlence, içinde dans, müzik, giyim-kuşam, yiyecek ve içecek, tiyatro, edebiyat, oyun, sinema, moda, festival, şenlik, animasyon vb. pek çok gelenek yer alır. Diğer bir ifadeyle karmaşık bir sistem olan eğlence, kültürün, birçok kültürel geleneğin yaratılma, aktarılma, değiştirilme, özetle yaşatılma ortamıdır. Dolayısıyla eğlencenin araştırılması, birbiriyle ilişkili çeşitli geleneklerin de incelenmesi anlamına gelmektedir(Özdemir, 2005). Müzik sanatı birçok eğlence fikrinin en değişmez temel yapı taşlarından biri olarak karşımıza çıkmaktadır. Farklı din, dil ve kültürel yaşantıya sahip olan toplumların, eğlenme ihtiyacına müzik sanatı da katkı sağlamaktadır.

$\mathrm{Bu}$ durum, eğlence sektörünü ve bu sektörde çalışan meslek gruplarını ortaya çıkarmıştır. Eğlence müzisyenliği de bu mesleklerden biri olarak karşımıza çıkmaktadır. Eğlence sektörü müzisyenliği denilince ses ya da çalgı performansı ile toplumun eğlenme ihtiyacını karşılama noktasında hizmet veren kişiler akla gelmektedir. Eğlence sektörü müzisyenliği kavramı Türk toplumunda farklı şekillerde yer edinmiş ve bu durum atasözlerine dahi yansımıştır. Örneğin, "kızını boş bırakırsan ya davulcuya varır, ya zurnacıya" sözü geçmişte Türk toplumun eğlence müzisyenliğine olumsuz bir bakış açısının yerleşmiş olabileceği gibi bir izlenim bırakmaktadır. 21. Yüzyılda medya ve iletişim araçlarının gelişmesine paralel olarak eğlence sektörü müzisyenliği kavramını etkileyen sosyo-kültürel, eğitimsel ve ekonomik sebepler daha belirleyici bir hal almıştır. Bu sebeple günümüzde, eğlence sektörü müzisyenliği kavramı, bireyin mesleki eğitim seviyesi, gelir seviyesi ve popülaritesi gibi değişkenlerle yeniden değerlendirilme noktasına gelmiştir. Eğlence sektörü müzisyenliği kavramı günümüzde sınırları daha da genişlemiş ve toplumda farklı bakış açılarıyla yeniden değerlendirilen bir meslek olarak karşımızdadır. 


\subsection{Eğlence Sektörü Müzisyenliğine Toplumsal Bakıș}

Türk toplumunda, eğlence sektörü müzisyenliğine genel olarak ekonomik, sosyal, kültürel ve psikolojik olmak üzere dört farklı bakış açısıyla yaklaşmak mümkündür. Bunlara kısaca göz atılacak olursa:

\subsubsection{Ekonomik Yönü ile Bakış}

Ekonominin çok önemli olduğu günümüz toplumunda, çeşitli meslek gruplarının ekonomik kazancı ile toplumdaki bireylerin mesleklere bakışının benzerlik göstermesi de bu durumun doğal bir sonucudur. Bir meslek, ekonomik açıdan bireyleri rahat bir hayat yaşatabilecek kadar para kazandırabiliyor ise ekonominin son derece önemli olduğu toplumumuzda, o mesleğe daha pozitif bir bakış açısı olacağını söylemek mümkündür. Bunun yanında az veya çok miktarda kazanç sağlayan birçok meslek mevcuttur. Meslek gruplarındaki ekonomik kazancın miktarı neye göre belirleniyorsa, meslek çalışanları da bu doğrultuda az veya çok kazanç elde etmektedirler.

Ekonomik kazancın miktarı için; bireyin eğitim seviyesi ve mesleki bilgi birikimi önemli bir yer tutmaktadır. Mesleki bilgi birikimi yüksek olan bir birey aynı zamanda mesleki tecrübenin verdiği avantaj ile daha fazla kazanç elde edebilmektedir. Ekonomik açıdan daha iyi eğitim almış ve kendini daha iyi geliştirmiş bireyler de mesleki açıdan daha düşük eğitime sahip ve tecrübesiz bireylere göre daha fazla kazanç elde edebilmektedirler. Birçok meslekte olduğu gibi, eğlence sektöründe çalışan müzisyenler içinde eğitim seviyesi ve mesleki bilgi birikimi önemli bir yer tutar.

\subsubsection{Sosyal Statü Yönüyle Bakış}

Toplumun, eğlence sektörü müzisyenlerine sosyal statü yönünden bakışı, ekonomik temele dayalı bakış açıları ile paralellik göstermektedir. Toplumun sosyal statü yönü ile eğlence sektörü müzisyenlerine bakışının geçmişten günümüze farklı noktalara gelmiş olduğunu ifade etmek mümkündür. Geçmişte, müzisyenlik mesleği ülkemizde eğitimsel bir temele dayalı olarak hareket etmemiştir. Geçmişte yaşayan insanların bir bölümü, usta çırak ilişkisi ile herhangi bir eğitim ve bilgi birikimi olmadan, müzisyenlik mesleğine atılmışlardır. Sosyal, sağlık vb. güvencelere sahip olmadıkları için toplumda sosyal statü yönü ile düşük noktalara geldikleri günler olmuştur. Bunun yanında toplum içerisindeki sosyal statüyü en çok etkileyen kurumlardan birisi olan eğitim kurumu, bu meslekte çok eski yıllara dayanmamaktadır.

Müzik ile ilgili eğitim kurumlarının açılışı Cumhuriyet Dönemi' nden sonra hız kazanmaya başlamıştır. Sosyal statünün en önemli dayanaklarından biri olan eğitimden yoksun olan bir mesleğe toplumun pozitif bir bakış açısı sergileyeceği de düşünülemez. Bu nedenle, gelir seviyesi toplumun bakış açısında önemli bir etken olsa da, eğitim kurumlarının müzik alanında geçmişi çok eskiye dayalı olmadığı için, eğlence sektörü müzisyenliği mesleğine ve bu mesleği icra eden bireylere, toplumda geçmişin de etkisi ile bu güne taşınan olumsuz bir bakış sergilendiği sonucu çıkarılabilir.

\subsubsection{Kültürel Yönüyle Bakış}

"Kültür, tarihsel, toplumsal gelişme süreci içinde yaratılan bütün maddi ve manevi değerler ile bunları yaratmada, sonraki nesillere iletmede kullanılan, insanın doğal ve toplumsal çevresine egemenliğinin ölçüsünü gösteren araçların bütünüdür”.(Türk Dil Kurumu, 2005: 
1282) Yaşayan her toplum yaşayış farklılıklarını geçmiş nesillerden gelecek nesillere aktarmaya devam etmektedir. Bu nedenle kültür olgusu, bir toplumu diğer toplumlardan ayıran önemli yapı taşlarından biri olarak karşımıza çıkmaktadır.“Altaş’ın aktardığı üzere bir eğitimci olarak Ferhan Oğuzkan kültürü, bir toplumu ya da halkı duyuş, düşünüş, yaşayış bakımından öbürlerinden ayıran maddi manevi ürünlerin tümü olarak tanımlamıştır”.(Altaş, 2003:10-11).

Geçmişte yaşayan toplumun bireyleri örf, adet, gelenek ve göreneklere uygun olarak kültürel farklılıklarını geleceğe taşıyıp toplumlar arası farklılıklara ve bu zengin renk çeşitliliğine önemsenecek ölçüde 1şık tutmaya devam etmektedir. Ülkemizde var olan birçok kültürel farklılıkları çeşitli bölgelerdeki farklı yaşayış biçimleri olduğu gibi, sanat dalları ve meslek grupları da belirleyebilmektedir. Bunlardan birisi de toplumun müzik kültürüdür. Müzisyenlerin geçmişlerinde kazandıkları bilgi ve beceri birikimlerini gelecek kuşaklara aktarmaları gerekmektedir. Fakat daha önce de bahsedildiği gibi ekonomik ve sosyal statü yönü ile belirli bir konumda olmayan bir bireyin kültürel olarak da kendini yeterince geliştiremediğini söylemek mümkündür. Yeterli ölçüde ekonomik imkânlara sahip olamayan bireyler, sosyal yönden kendilerini geliştirecek imkânları da elde edememektedirler. Bu nedenle, toplumun kültürel yönü ile gelişmişliğini, toplumu oluşturan bireylerin ekonomik ve sosyal yapısı ile ilişkilendirmek mümkündür. Gelir seviyesi yüksek olan bireyler tiyatro, sinema, konser vb. sosyal aktivitelere katılabilirken, gelir seviyesi düşük olan bireylerin yaşantılarında bu tür sosyal faaliyetlere yer vermeleri ekonomik nedenlerden dolayı beklenemez. Eğlence sektörü müzisyenlerinin gelir seviyesi de düşünüldüğünde standart (düzenli) bir ekonomik gelire sahip olmamaları nedeni ile bu tür sosyal faaliyetlere katılma olasılıkları düşüktür. Bunun yanında eğlence sektöründe görev alan bir müzisyenin ekonomik yönden yeterli imkânı olması durumunda bile genellikle sosyal faaliyetlerin (tiyatro, sinema, konser, vs.) çalışma saatleri ile aynı zamana denk gelmesinden dolayı söz konusu aktivitelere katılmaları da mümkün olmayacaktır. Aynı zamanda günün geç saatlerine kadar çalıştıkları için geçimlerini sağlamakla sorumlu oldukları ailelerinin de kültürel faaliyetlere katılma imkânları bulunmamaktadır. Bu durum bireyin ekonomik ve sosyal yaşantısının aynı zamanda kültürel yaşantısına da etki edebildiğini gözler önüne sermektedir.

\subsubsection{Psikolojik Yönüyle Bakış}

Eğlence sektörü müzisyenleri, uğraştıkları sanatın da etkisiyle kırılgan bir yapıya sahip oldukları için, günlük yaşantılarında karşılaştıkları olumsuz olaylardan çok çabuk etkilenebilmektedirler. Bu kırılganlık anları eğlence sektörü müzisyenlerini farklı psikolojilere yönlendirebilir. Eğlence sektörü müzisyenlerinin çalışma şartları, ekonomik sorumlulukları ve bakmakla yükümlü oldukları aileleri de göze alındığında, güncel hayatlarında içine kapanık bir hayat sergilemeleri kaçınılmazdır.

Toplumun bireylerine genel olarak bakıldığında hemen hemen herkes bir müzik aleti ile hobi olarak ilgilenip çalmak istemektedir. Fakat eğlence sektörü müzisyenliği mesleğine nedense sıcak bakılmamaktadır. Bu meleği icra etme fikrine toplumun büyük bir bölümü olumsuz bakmaktadır. Bu olumsuz düşünceye toplumda geçmişten günümüze kadar gelen ön yargıların neden olduğunu ifade edebiliriz. Çünkü toplum eğlence sektörü müzisyenliği mesleğini, geçmişten günümüze kadar geldiği süreçte anlık bir kazanç getiren, ekonomik olarak standart bir geliri olmayan bir meslek olarak görmektedir. Eğlence sektörü müzisyenleri bu olumsuzluklar nedeniyle aylık ekonomik bütçelerini de ayarlayamamaktadırlar. Çünkü sahne aldıkları gece bir sonraki işlerinin hangi gün olacağını veya ne kadar ücret alacaklarını bilememektedirler. Bazı eğlence sektörü müzisyenleri yılın belirli aylarında iş imkânı bulabilirken bazıları haftanın belirli günlerinde çalışmaktadırlar. Aynı zamanda sürekli 
çalışma imkânı bulamayan müzisyenler de oldukça fazladır.

Eğlence sektörü müzisyenliği mesleği genel olarak süreklilik arz eden bir meslek olmadığı için eğlence müziği yapan bireyler ekonomik olarak sıkıntı yaşayabilmektedirler. Yakın çevrelerinden veya ailelerinden borç para almaları durumunda ise standart gelirleri olmadığından tekrar ödeyebilme garantileri de söz konusu olmamaktadır. Müzisyen iyi niyetli de olsa ekonomik bütçesinde kararlı bir durum söz konusu olmadığından dolayı verdiği sözü yerine getiremeyebilir. Bu durum toplumda eğlence sektörü müzisyenleri hakkında sözlerine güvenilmeyen bireylermiş gibi olumsuz bir yargı oluşmasına sebep olabilir. Bunun yanında eğlence sektörü müzisyenlerinin mesleklerini icra ettikleri mekânlar, genellikle insanlara sarhoşluk etkisi verecek maddelerin tüketildiği mekânlardır. Bu tür yerler toplum olarak olumlu bakılmayan, sarhoş, berduş, ayyaş diye tabir edilen bireylerin uğradığı mekânlar olarak bilinmektedir. Eğlence sektörü müzisyenleri bu tür mekânlarla çok içli dışlı olmaları nedeniyle, müşterilerle aynı psikolojide olmasalar bile toplum tarafından o mekândaki bireylerle bir tutulup olumsuz bir bakışa maruz kalabilmektedirler. Burada, toplumun eğlence sektörü müzisyenlerine, çalıştıkları mekânlardan ve bu mekânların müşteri potansiyelinden dolayı ön yargılı bir tutum sergilediği düşünülebilir. Eğlence sektörü müzisyenlerinin her gece kulüp veya eğlence yerlerine gitmesi söz konusu değildir. Eğlence sektörü müzisyenleri bu tür mekânlara toplumda oluşan olumsuz düşüncenin (bakışın) aksine para kazanmak, sorumlu oldukları ailelerinin geçimlerini sağlamak amacıyla gitmektedirler. Fakat toplumda eğlence sektörü müzisyenlerinin gece kulüplerine veya bu tür eğlence yerlerine tıpk1 o mekânlarda eğlenen bireyler gibi eğlenme amacı ile gittiği izlenimi oluşmakta ve bu tür mekânlardaki bireyler ile eğlence sektörü müzisyenleri bir tutulup var olan bu ön yargı aşılamamaktadır.

\section{Yöntem}

\subsection{Araştırmanın Amacı ve Önemi}

$\mathrm{Bu}$ araştırmanın amacı, toplum içerisindeki bireylerin eğlence sektörü müzisyenliği mesleğine yönelik düşüncelerini etkileyen sosyo-kültürel, ekonomik ve diğer etkenleri ve eğlence sektörü müzisyenliğine yönelik toplumsal bakış açılarını tespit etmektir. Araştırmanın, eğlence sektörü müzisyenliğine yönelik sosyo- kültürel ve ekonomik olarak toplumsal bakış açılarını ortaya koymayı hedeflemesi bakımından önem taşıdığı düşünülmektedir.

\subsection{Araştırmanın Modeli}

Araştırma modeli, bir araştırmanın amacına uygun ve ekonomik olarak verilerin toplanması, çözümlenebilmesi için gerekli koşulları düzenlemeye denir (Karasar,1984,79). Bu araştırmada, Tarama modeli kullanılmıştır. Tarama Modeli; geçmişte ya da o anda var olan bir durumu var olduğu şekliyle betimlemeyen, tanımlamayı amaçlayan araştırma yaklaşımıdır. Araştırmaya konu olan her neyse onları değiştirme ve etkileme çabası yoktur bu modelde bilinmek istenen şey meydandadır. Amaç o şeyi doğru bir şekilde gözlemleyip belirleyebilmektir. Asıl amaç değiştirmeye kalkmadan gözlemektir (Karasar,1984,79). Bu araştırmada, konu hakkında temel bilimsel verilerin edinilmesinde dijital ve yazılı kaynak taraması yapılmıştır. Bireylerin konu ile düşüncelerine yönelik verilerin toplanmasında anket tekniğinden faydalanılmış ve araştırma sonuçlarına elde edilen istatistik verilere dayanarak ulaşılmaya çalışılmıştır. 


\subsection{Evren ve Örneklem}

Araştırmanın evrenini Malatya ilinde farklı sosyo-kültürel ve ekonomik yaşam düzeylerinde yaşayan farklı yaşlarda ve cinslerdeki bireyler, örneklemini ise rastlamsal yöntemle belirlenen ve anket uygulaması yapılan 728 örneklem oluşturmaktadır. Araştırmada kullanılan veriler, anket tekniği ve doküman (dijital, yazılı, görsel ve işitsel) yöntemi ile elde edilmiştir.

\section{Bulgular ve Yorum}

Bu bölümde araştırmaya yönelik anket sorularından elde edilen veriler (\%) değerler olarak hesaplanmış grafikler halinde düzenlenmiş ve yorumlanmıştır.

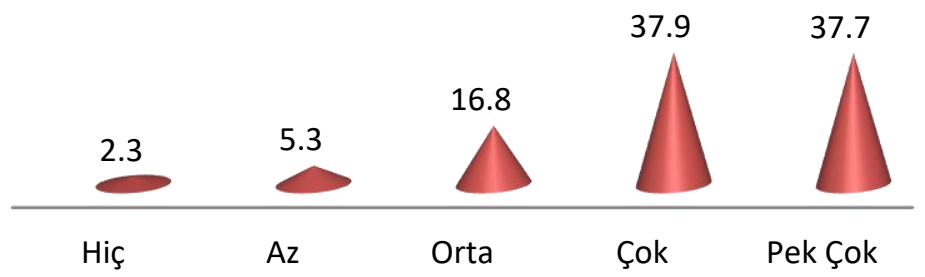

Grafik 1: Eğlence sektörü müzisyeninin aldığı mesleki eğitiminin niteliği toplumdaki bireyler arasında saygın bir yer edinmesinde sizce ne kadar önemlidir?

Grafik 1'de “eğlence sektörü müzisyeninin toplumdaki bireyler arasında saygın bir yer edinmesinde aldığı mesleki eğitimin niteliği ve derecesi sizce ne kadar önemlidir?" sorusuna örneklemlerin ağırlıklı olarak çok ve pek çok yanıtını verdikleri görülmektedir. Bu verilere dayanarak, eğlence sektörü müzisyeninin toplumdaki bireyler arasında saygın bir yer edinmesinde aldığı mesleki eğitimin niteliği ve derecesinin büyük ölçüde önem taşıdığını söylemek mümkündür. Bu konuda "hiç" ya da "az" yanıtı veren karşıt fikirli örneklem sayısının sadece \% 7,6 civarında olduğu görülmektedir.

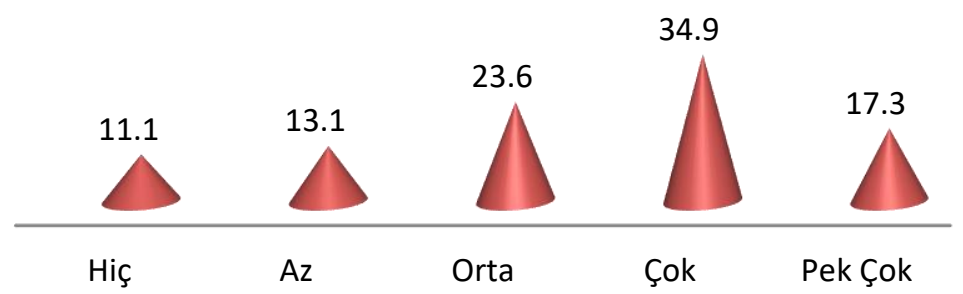

Grafik 2: Eğlence sektörü müzisyeninin mesleki kazancının miktarı toplumdaki bireyler arasında saygın bir yer edinmesinde sizce ne kadar önemlidir?

Grafik 2 incelendiğinde örneklemlerin büyük bir bölümü, eğlence sektörü müzisyeninin toplumdaki bireyler arasında saygın bir yer edinmesinde mesleki kazancının miktarı sorusuna büyük ölçüde "çok" ve "pek çok" yanıtını verdiği görülmektedir. Bu verilere dayanarak eğlence sektörü müzisyeninin toplumdaki bireyler arasında saygın bir yer edinmesinde mesleki kazancının miktarının önemli olduğunu söylemek mümkündür. Yine grafik incelendiğinde, örneklemlerin \% 11,1 ve 13,1 'i eğlence sektörü müzisyenlerinin mesleki 
kazancının miktarının çok önemli olmadığını düşünmektedir.

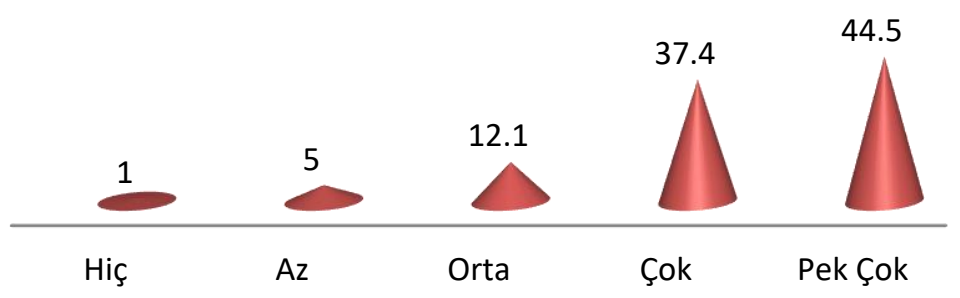

Grafik 3: Eğlence sektörü müzisyeninin çalgısındaki (yorumundaki) beceri ve performans seviyesinin miktarı toplumdaki bireyler arasında saygın bir yer edinmesinde sizce ne kadar önemlidir?

Grafik 3 incelendiğinde eğlence sektörü müzisyeninin toplumdaki bireyler arasında saygın bir yer edinmesinde çalgısındaki (yorumundaki) beceri ve performans seviyesinin miktarının önemi sorulmuştur. $\mathrm{Bu}$ soruda örneklemlerin \% 82,9' luk büyük bir kısmı müzisyenlerin toplumda saygın bir yer edinmesinde, çalgısındaki (yorumundaki) beceri ve performans seviyesinin miktarının önemli olduğunu belirtmiştir. Bu grafikteki verilere dayanarak, eğlence sektörü müzisyeninin toplumdaki bireyler arasında saygın bir yer edinmesinde çalgısındaki (yorumundaki) beceri ve performans seviyesinin miktarının önemli olduğunu söylemek mümkündür.

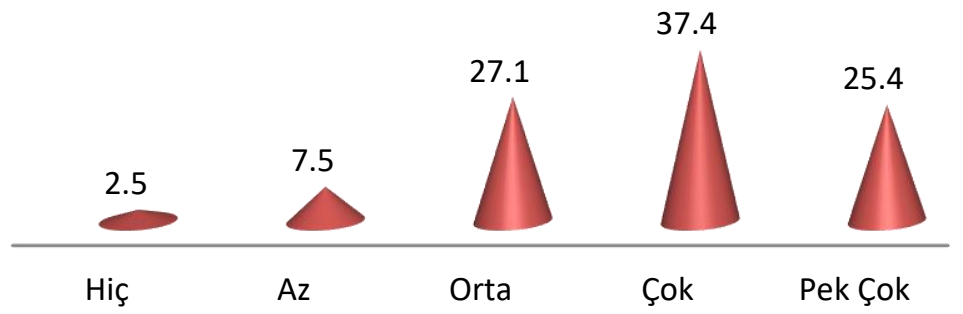

Grafik 4: Eğlence sektörü müzisyeninin görsel ve işitsel medya araçlarında yer alma oranı (popülaritesi) toplumdaki bireyler arasında saygın bir yer edinmesinde sizce ne kadar önemlidir?

Grafik 4'de eğlence sektörü müzisyeninin toplumdaki bireyler arasında saygın bir yer edinmesinde görsel ve işitsel medya araçlarında yer alma oranı (popülaritesi)' nin ne derece önemli olduğu sorusu yöneltilmiştir. Bu soruya örneklemlerin ağırlıklı olarak "çok" ve "pek çok" yanıtını verdiği görülmektedir. Bu verilere dayanarak eğlence sektörü müzisyeninin toplumdaki bireyler arasında saygın bir yer edinmesinde görsel ve işitsel medya araçlarında yer alma oranının büyük ölçüde önem taşıdığını söylemek mümkündür. 


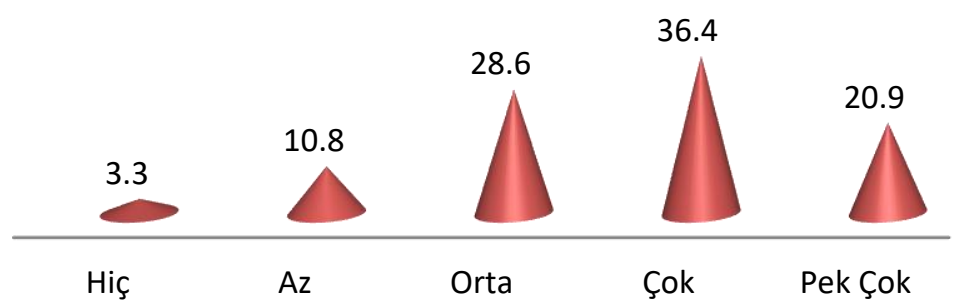

Grafik 5: Eğlence sektörü müzisyeninin sadece mesleki çalışmaları ile medyada yer alması toplumdaki bireyler arasında saygın bir yer edinmesinde sizce ne kadar önemlidir?

Grafik 5 'de "eğlence sektörü müzisyeninin toplumdaki bireyler arasında saygın bir yer edinmesinde sadece mesleki çalışmaları ile medyada yer almasının ne derece önemli olduğu" sorusuna örneklemlerin \% 36,4' ü “çok" ve \% 20,9' u "pek çok” yanıtını vermiştir. Bu verilere dayanarak eğlence sektörü müzisyeninin toplumdaki bireyler arasında saygın bir yer edinmesinde sadece mesleki çalışmaları ile medyada yer almasının önemli olduğunu söylemek mümkündür. Bu konuda karşıt fikirli örneklemlerin oranı sadece \% 14,1 olarak görülmektedir.

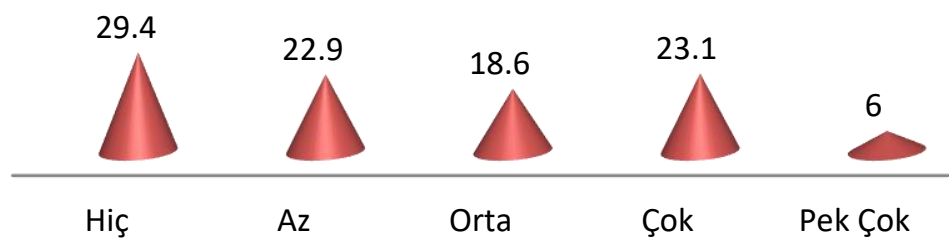

Grafik 6: Eğlence sektörü müzisyeninin politik görüşü toplumdaki bireyler arasında saygın bir yer edinmesinde sizce ne kadar önemlidir?

Grafik 6'da eğlence sektörü müzisyeninin toplumdaki bireyler arasında saygın bir yer edinmesinde politik görüşünün bir önemi olup olmadiğ 1 sorulmuştur. Örneklemlerin \% 52,3' ü az ve hiç bir öneme sahip olmadığını düşünürken, \% 18,6' sı orta derece önemli olduğunu düşünmektedir. Örneklemlerin \% 29,1 lik kısmı ise eğlence sektörü müzisyeninin politik görüşünün de toplumdaki bireyler arasında saygın bir yer edinmesinde büyük bir öneme sahip olduğunu düşünmektedir. Bu verilere göre her ne kadar toplumun bir kısmı eğlence sektörü müzisyeninin politik görüşünün önemli olduğunu belirtmiş olsalar da, toplumun büyük bir kesiminin bu görüşün aksine fikir belirtmiş oldukları görülmektedir. 


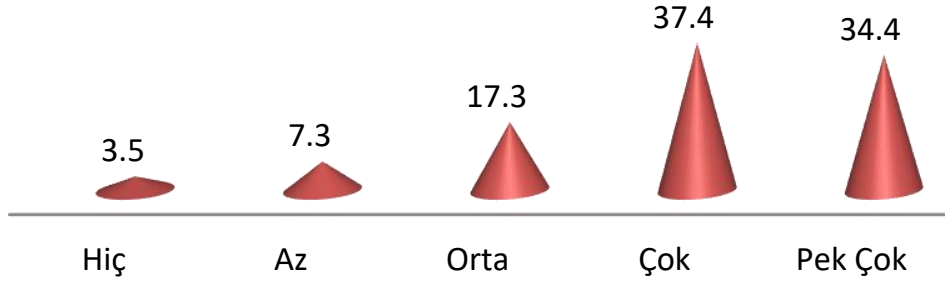

Grafik 7: Eğlence sektörü müzisyeninin yardımseverlik ve cömertlik gibi insanı değerlere sahip olması toplumdaki bireyler arasında saygın bir yer edinmesinde sizce ne kadar önemlidir?

Grafik 7'de eğlence sektörü müzisyeninin toplumdaki bireyler arasında saygın bir yer edinmesinde yardımseverlik ve cömertlik gibi insanı değerlere sahip olmasının önemi sorulmuştur. Grafik incelendiğinde toplumun \% 71,8 lik büyük bir kesimi bu konunun önemli olduğu görüşünde birleşmişlerdir. Örneklemlerin yalnızca \% 10,8' lik bir kısmı ise, eğlence sektörü müzisyeninin toplumdaki bireyler arasında saygın bir yer edinmesinde yardımseverlik ve cömertlik gibi insanı değerlere sahip olmasının önemli olmadığı görüşündedir. Bu verilere dayanarak eğlence sektöründe görev yapan bir müzisyenin yardımseverlik ve cömertlik gibi insani değerlere sahip olması gerektiğini söylemek mümkündür.

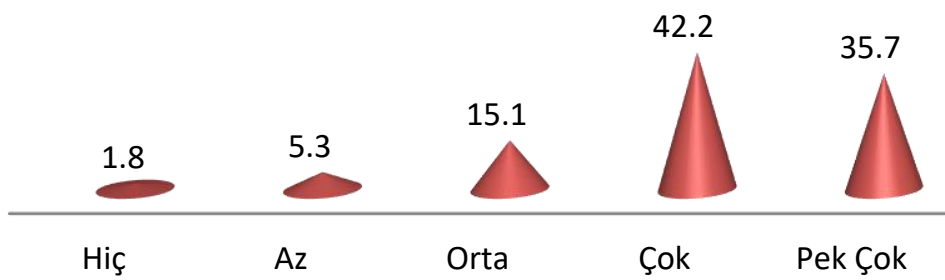

Grafik 8: Eğlence sektörü müzisyeninin kültürel seviyesi ve olaylara pozitif bir bakış açısı sergilemesi toplumdaki bireyler arasında saygın bir yer edinmesinde sizce ne kadar önemlidir?

Grafik 8'de eğlence sektörü müzisyeninin toplumdaki bireyler arasında saygın bir yer edinmesinde kültürel seviyesi ve olaylara pozitif bakış açısı sergilemesinin önemi sorulmuştur. Örneklemlerin \% 77,9' luk büyük bir kısmı eğlence sektörü müzisyeninin kültürel seviyesinin ve olaylara pozitif bakış açısı sergilemesinin önemli olduğu görüşünde birleşmişlerdir. Örneklemlerin \% 20,4' lük kısmı bu konunun çok önemli olmadığını yine örneklemlerin sadece \% 1,8' lik bir kısmı ise eğlence sektörü müzisyeninin toplumdaki bireyler arasında saygın bir yer edinmesinde kültürel seviyesi ve olaylara pozitif bakış açısı sergilemesinin hiçbir önemi olmadığını düşünmektedir. Bu verilere göre eğlence sektörü müzisyeninin toplumdaki bireyler arasında saygın bir yer edinmesinde kültürel seviyesi ve olaylara pozitif bakış açısı sergilemesinin önemli olduğu söylenebilir. 


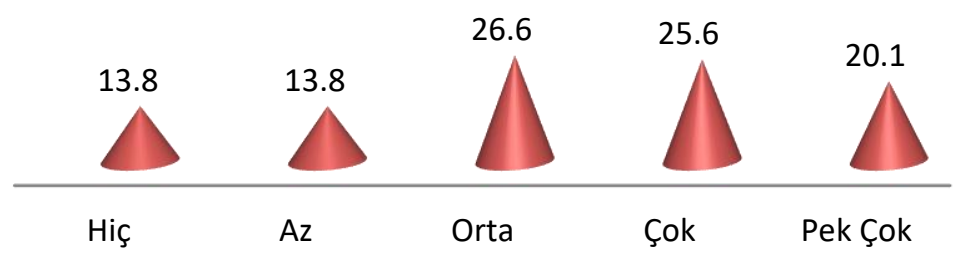

Grafik 9: Eğlence sektörü müzisyeninin aynı zamanda itibarlı başka bir mesleğe sahip olması, toplumda saygın bir yer edinmesinde sizce ne derece önemlidir?

Grafik 9'da saygın bir mesleğe sahip olan bireylerin aynı zamanda eğlence sektörü müzisyenliği mesleğini icra etmelerinin toplumun bakış açısını ne yönde değiştireceği sorusu sorulmuştur. Grafik incelendiğinde, örneklemlerin büyük bir kısmı bu soruya orta, çok ve pek çok yanıtı verirken sadece 27,6 ' l1k bir kesim ise eğlence sektörü müzisyeninin toplumda saygın bir yer edinmesinde saygın başka bir meslek sahibi olmasının önemli olmadığ görüşündedir. $\mathrm{Bu}$ grafiğe göre; eğlence sektörü müzisyeninin toplumda saygın bir yer edinmesinde toplum tarafından saygın olarak görülen başka bir meslek sahibi olmasının da önemli bir rol üstlendiğini söylemek mümkündür.

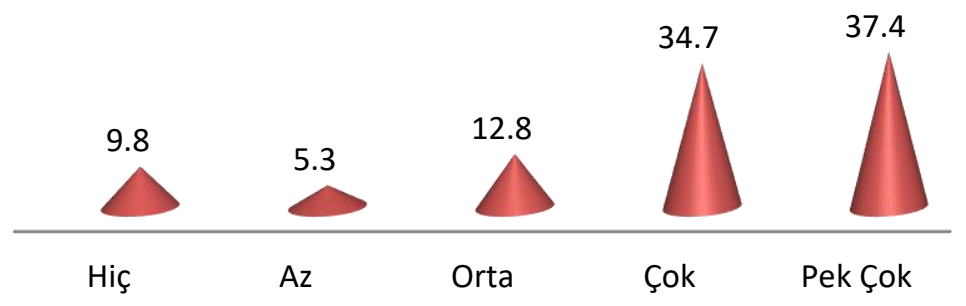

Grafik 10: Düğününüzde veya bir yakınınızın düğününde eğlence sektörü müzisyenlerinin sahne alması fikrini ne ölçüde desteklersiniz?

Grafik 10'da örneklemlere bir yakınlarının veya çocuklarının düğününde müzisyenlerin çalmasını ister misiniz sorusu yöneltilmiştir. Bu soruya örneklemlerin \% 72,1' lik büyük bir kesim çok ve pek çok yanıtını vermiştir. Veriler incelendiğinde bu soruya örneklemlerin sadece \% 27,9 oranındaki örneklemin ise orta, az ve hiç yanıtını verdikleri görülmektedir. Grafiğe göre toplumun büyük bir kısmının eğlence sektörü müzisyenlerinin yakınlarının veya çocuklarının düğünlerine katkı sağlamasına olumlu baktıklarını söylemek mümkündür.

\section{Sonuçlar ve öneriler}

\subsection{Sonuçlar}

$\mathrm{Bu}$ araştırmada elde edilen veriler doğrultusunda ulaşılan sonuçlar, aşağıda maddeler halinde sunulmaktadır.

Eğlence sektörü müzisyenlerinin toplumdaki bireyler arasında saygın bir yer edinmesinde: 
- Aldığı mesleki eğitimin niteliği ve derecesinin büyük ölçüde önem taşıdığ1,

- Mesleki kazancının miktarının önemli olduğu,

- Mesleki beceri ve performans seviyesinin önemli olduğu,

- Görsel ve işitsel medya araçlarında yer alma oranının büyük önem taşıdığı,

- Yardımseverlik ve cömertlik gibi insani değerlere sahip olmasının önemli görüldüğü,

- Kültürel seviyesi ve olaylara pozitif bakış açısı sergilemesinin önemli olduğu,

- Saygın başka bir meslek sahibi olmasının da önemli görüldüğü,

- Konu ile ilgili eğitim seviyesi değişkeninin kısmen etkili olduğu, eğitim seviyesi yüksek örneklemlerin eğlence sektörü müzisyenliği mesleğine birçok yönü ile daha olumlu yaklaştığı.

Araştırmada elde edilen sonuçlardan önemli görülenleridir.

\section{2. Öneriler}

$\mathrm{Bu}$ araştırmada ulaşılan sonuçlar doğrultusunda düşünülen çözüm önerileri aşağıda sunulmaktadir:

Eğlence sektörü müzisyenliği yapan bireyler, toplumsal bakış açısının olumlu yönde değişmesi adına eğitim durumlarında iyileştirmeye gitmeli ve özellikle mesleki alanlarda eğitim durumlarını daha iyi seviyelere çıkartmalıdır. Eğlence sektörü müzisyenleri, mesleki beceri ve performanslarını geliştirmenin yanı sıra, kültürel eğitimlerini de tamamlamalıdır. Eğlence sektörü müzisyenleri, performanslarını sergiledikleri mekânların kalitesinin kendilerine yönelik toplumsal bakışın değişebilmesi bakımından önemli olduğunu bilmelidirler,

Eğlence sektörü müzisyenleri, toplum içerisinde daha güvenilir insanlar olarak bilinmek adına daha dikkatli olmalı ve güven uyandıracak mesleki ve insani hareketleri daha sık yapmalıdır. Toplumsal yapı içerisinde rol alan bireyler ise, eğlence sektörü müzisyenlerinin toplumun önemli bir parçası olduğunu ve kendilerinin de zaman zaman bu mesleğin mensuplarına ihtiyaç duyduklarını unutmamalıdır.

Geçmişten gelen ve özellikle bu konudaki gerek mesleki, gerekse kültürel eğitim yetersizliklerinden kaynaklandığı düşünülen eğlence sektörü müzisyenliğine karşı toplum içerisindeki olumsuz bakış açısı ve önyargı değişmelidir. Bireysel eksiklikler ve hataların tümü eğlence müziği yapan bireylere mal edilmemelidir.

\section{Kaynakça}

1. ALTAŞ Nurullah, (2003), Çok Kültürlülük ve Din Eğitimi, Nobel Yayınları, Ankara.

2. BOSSHART, L. \& MACCONI, I. (1998), "Defining entertaintment", Communication Research Trends, Vol. 18, No: 3.

3. FETTAHOĞLU, Selahattin, (2003), Konfüçyüs ve Öğretisi, Ondokuz Mayıs Üniversitesi İlahiyat Fakültesi Dergisi_s:322.

4. KARASAR, N. (1984), Bilimsel Araştırma Metodu, Hacettepe Taş Kitapçılık, Ankara

5. ÖZDEMİ, Nebi, (2005), Cumhuriyet Dönemi Türk Eğlence Kültürü, Akçay Yayınları, Ankara.

6. TDK (Türk Dil Kurumu), (2005), Türkçe Sözlük, Türk Dil Kurumu Yayınları, Ankara.

7. ZİLLMANN, D. (2000), "The Coming of Media Entertainment", Media Entertainment: The Psychology of its Appeal, Eds. D. Zillmann \& P. Vorderer, Mahwah, New Jersey, Lawrence Erlbaum Associates. 